\title{
A cross sectional study of coagulation profile in term normotensive pregnancy and hypertensive disorders like preeclampsia, eclampsia
}

\author{
Madana Jyotsna Priya, Gomathy Ethiraj*, Sheela Shivamonga Rangappa
}

Department of Obstetrics and Gynaecology, Sri Devaraj Urs Medical College, Sri Devaraj Urs Academy of Higher Education and Research (SDUAHER), Tamaka, Kolar, Karnataka, India

Received: 04 September 2021

Revised: 17 October 2021

Accepted: 18 October 2021

*Correspondence:

Dr. Gomathy Ethiraj,

E-mail: egomathy72@yahoo.com

Copyright: () the author(s), publisher and licensee Medip Academy. This is an open-access article distributed under the terms of the Creative Commons Attribution Non-Commercial License, which permits unrestricted non-commercial use, distribution, and reproduction in any medium, provided the original work is properly cited.

\section{ABSTRACT}

Background: Normal pregnancy is a procoagulant state. In preeclampsia, this process of coagulation is exaggerated and will lead to further effects on the mother, placenta and fetus. The purpose of this study is to find out the changes that occur in the coagulation indices in pregnancy induced hypertension as compared to that in normal pregnancy which will help in the better management of patients with pregnancy induced Hypertension.

Methods: This was a cross sectional study in 116 patients with normotensive and patients with hypertensive disorders in pregnancy conducted in a tertiary medical facility. Coagulation parameters like platelet count, prothrombin time, activated partial thromboplastin time, bleeding time and clotting time were evaluated. We used the difference of 5\% in mean PT between normotensive (control) and hypertensive patients by applying $80 \%$ power and alpha error of $5 \%$.

Results: Platelet counts of study population were significantly related to the prognosis of the patient. The cut off values of major parameters like aPtt, BT with the outcome were with p value of 0.37 and 0.76 respectively.

Conclusions: In cases of pregnant complicated with HDP, parameters like coagulation profile, bleeding time, clotting time were probably useful indicators in the early diagnosis and management of severe morbidity of the mother and the fetus. Further prospective trials with large study population are warranted to evident these results.

Keywords: Coagulation profile, Hypertensive disorders in pregnancy, HELLP syndrome

\section{INTRODUCTION}

Preeclampsia, a multiorgan hypertensive disease in pregnancy that affects $2 \%$ to 896 of pregnancies globally. ${ }^{1}$ In the United States, the rate of preeclampsia has increased dramatically in the last 2 to 3 decades Worldwide, pregnancies affected by preeclampsia, and preeclampsia spectrum disorders, contribute to a significant portion of severe maternal morbidity and mortality. ${ }^{2}$ Preeclampsia comprises a large and varied disease spectrum. The diagnosis of preeclampsia and preeclampsia with severe features relies on hypertension with the addition of laboratory abnormalities that reveal evidence of end-organ damage due to the disease. ${ }^{3}$

Normal pregnancy is a procoagulant state, characterized by an increase in many procoagulant factors and markers of thrombin generation. ${ }^{4}$ In preeclampsia, this process of physiological activation of coagulation is exaggerated and includes excessive platelet activation, increased fibrin degradation products and intervillous fibrin deposition in the placenta. Due to repeated activation of the coagulation cascade and because of the endothelial damage being experienced as the placenta attempts to provide for the fetus, be excess produced fibrin is seen as 
thrombotic microangiopathies. ${ }^{3}$ Also, this cases consumption of platelets and clotting factors, thereby reducing the total platelet count and increasing PT and all in preeclamptic women in India, and in some cases leading to DIC (disseminated intravascular coagulation) and HELLP (haemolysis, elevated liver enzymes. Low platelet count) syndrome. ${ }^{5}$ Many studies concluded that when diagnosing preeclampsia fibrinogen levels, PT and PTT should be obtained only in women with thrombocytopenia, while other studies demonstrate that coagulation measures correlate well with preeclampsia complications and suggest that such tests should be performed routinely. ${ }^{7}$

\section{Aim and objectives}

Pre-eclampsia and eclampsia is a common cause of maternal morbidity and mortality. ${ }^{2}$ Accompanying preeclampsia and eclampsia, coagulation abnormalities are one of the commonest and the deadliest complications. $^{8}$ It is known that an underlying coagulation abnormality increases the risk of bleeding complications. So, we have to use correct and necessary laboratory tests for the diagnosis of complications of hypertensive disorders of pregnancy. ${ }^{6}$ Hence, this study is to find out the changes that occur in the coagulation indices in pregnancy induced hypertension as compared to that in normal pregnancy which will help in the better management of patients with pregnancy induced Hypertension. Objectives of the current study were to compare the coagulation profile in term (37 to 42 weeks of gestation) normal pregnancy, pre-eclamptic and eclamptic patient, to assess the severity of hypertensive disorders during pregnancy and to detect coagulation failure and its risks.

\section{METHODS}

\section{Study design, data source and sample size}

Current study was a cross sectional analytical study. Patients were selected as per inclusion and conclusion criteria after 37 weeks of gestation coming to RL Jalappa Hospital. Total numbers of study subjects were 116 .

\section{Procedure}

All the cases of obstetrics above 37 weeks were analysed for risks of hypertensive disorders and their outcome. This study was a cross sectional study conducted at department of obstetrics and gynaecology, RL Jalappa hospital attached to Sri Devaraj Urs medical college affiliated to Sri Devaraj Urs academy of higher education and research, Tamaka, Kolar and consisted cases of booked and referred obstetrics for a duration of 1 year from July 2020 to August 2021 and their outcome. All of them were subjected to detailed history, examination and investigation with the proforma as appended. All the cases were subjected to the following coagulation parameters like platelet count, prothrombin time, activated partial thromboplastin time, bleeding time and clotting time. Sample size $(n=116)$ estimated based on PT values. To detect a difference of $5 \%$ in mean PT between control (normotensive) and hypertensive patients (preeclampsia, eclampsia) by applying $80 \%$ power and alpha error of 5\%. Estimated sample size for each group 58 , total of 116 by using n Master 2.0 software.

\section{Inclusion criteria}

All booked and referred antenatal and intra-rural patients to our tertiary care institute of more than 37 weeks gestational age were included in the study.

\section{Exclusion criteria}

Referred and booked cases of less than 37 weeks booked gestation, post-partum referrals, gynaecological referrals, pre-existing medical disorders; diabetes mellitus, renal diseases, any coagulopathies, chronic hypertension, smokers, placental abruption or previa, sepsis and heavy vaginal bleeding were excluded from the study.

\section{Statistical methods}

Coagulation profile like PT, APTT etc., was considered as primary outcome variable. ICU admission, DIC etc., was considered as secondary outcome variables. Study groups were considered as primary explanatory variable. Descriptive analysis was carried out by mean and standard deviation for quantitative variables, frequency and proportion for categorical variables. Data was also represented using appropriate diagrams like pie diagram. Categorical outcomes were compared between study groups using Chi square test, $\mathrm{p}<0.05$ was considered statistically significant. CoGuide was used for statistical analysis.

\section{RESULTS}

The mean age of patients was in between 25 to 29 years in all the groups (Table 1). Most of the patients were in the 37 completed weeks and less than 38 weeks.

\section{Comparison of prothrombin time across study groups $(N=116)$}

Among the patients in hypertensive disorders in pregnancy and normotensive, prothrombin time was increased in $4(40 \%)$ patients of eclampsia, moderate in $10(35.7 \%)$ patients of severe preeclampsia, normal in 48 patients of normotensive individuals.

\section{Comparison of disseminated intravascular coagulation across study groups $(N=116)$}

Among the study groups, $5(50 \%)$ patients who were eclamptic and $2(7.14 \%)$ of severe pre-eclamptic patients had disseminated intravascular coagulation and no normotensive patients had DIC. 


\section{Comparison of ICU admission across study groups $(N=116)$}

Among the study population, $14.3 \%$ of severe preeclamptic and $30 \%$ of eclamptic patients needed ICU admission and rest of the population did not require the same. In the present study, $17.24 \%$ pregnant patients were preeclamptic, $24.14 \%$ were under severe preeclampsia group and $8.62 \%$ were eclamptic. $50 \%$ study group were normotensive pregnancies as described. As per the statistics maximum number of patients were in the mean age group of around 25-29 years and primigravidas were severe preeclamptic. Many were around the gestational age of 37-38 weeks. Pt, aPTt, INR were prolonged in cases of severe pre-eclampsia more. Bleeding time and clotting time were documented as shown in the tables. Thrombocytopenia was more in the cases of severe preeclampsia and eclampsia. $50 \%$ of the eclamptic patients had disseminated intravascular coagulation. 7 Patients in hypertensive group required ICU admission.

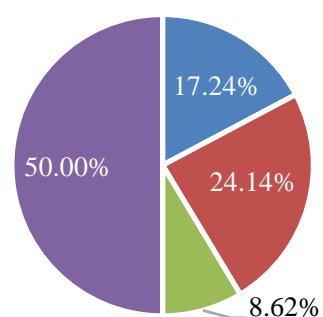

Figure 1: Distribution of sample size according to study groups $(\mathrm{N}=116)$.

Table 1: Comparison of age groups across study groups $(\mathrm{N}=116)$.

\begin{tabular}{|lllll|}
\hline Age groups (years) & $\begin{array}{l}\text { Study groups } \\
\text { Preeclampsia } \\
(\mathbf{N = 2 0 )} \\
\text { frequency (\%) }\end{array}$ & $\begin{array}{l}\text { Severe pre-eclampsia } \\
\mathbf{( N = 2 8 )} \\
\text { frequency }(\%)\end{array}$ & $\begin{array}{l}\text { Eclampsia (N=10) } \\
\text { frequency (\%) }\end{array}$ & $\begin{array}{l}\text { Normotensive } \\
(\mathbf{N}=58) \\
\text { frequency }(\%)\end{array}$ \\
\hline $\mathbf{2 0 - 2 4}$ & $5(25)$ & $8(28.57)$ & $1(10)$ & $15(25.86)$ \\
\hline $\mathbf{2 5}-\mathbf{2 9}$ & $9(45)$ & $13(46.43)$ & $7(70)$ & $26(44.83)$ \\
\hline $\mathbf{3 0 - 3 4}$ & $6(30)$ & $7(25)$ & $2(20)$ & $15(25.86)$ \\
\hline $\mathbf{3 3 5}$ & $0(0)$ & $0(0)$ & $0(0)$ & $2(3.45)$ \\
\hline
\end{tabular}

Table 2: Comparison of gravida across study groups $(\mathrm{N}=116)$.

\begin{tabular}{|c|c|c|c|c|c|c|}
\hline \multirow[b]{2}{*}{ Gravida } & \multicolumn{4}{|l|}{ Study groups } & \multirow[b]{2}{*}{ Chi square } & \multirow[b]{2}{*}{$\begin{array}{l}\mathbf{P} \\
\text { value }\end{array}$} \\
\hline & $\begin{array}{l}\text { Preeclampsia } \\
(\mathrm{N}=20) \\
\text { frequency }(\%)\end{array}$ & $\begin{array}{l}\text { Severe pre- } \\
\text { eclampsia }(\mathrm{N}=28) \\
\text { frequency }(\%)\end{array}$ & $\begin{array}{l}\text { Eclampsia } \\
(\mathrm{N}=10) \\
\text { frequency }(\%)\end{array}$ & $\begin{array}{l}\text { Normotensive } \\
(\mathrm{N}=58) \\
\text { frequency }(\%)\end{array}$ & & \\
\hline Primi & $11(55)$ & $21(75)$ & $8(80)$ & $32(53.33)$ & \multirow{2}{*}{4.95} & \multirow{2}{*}{0.18} \\
\hline Multi & $9(45)$ & $7(25)$ & $2(20)$ & $26(43.33)$ & & \\
\hline
\end{tabular}

Table 3: Comparison of gestational age across study groups $(\mathrm{N}=116)$.

\begin{tabular}{|c|c|c|c|c|c|c|}
\hline \multirow[b]{2}{*}{$\begin{array}{l}\text { Gestational age } \\
\text { (weeks) }\end{array}$} & \multicolumn{4}{|l|}{ Study groups } & \multirow[b]{2}{*}{ Chi square } & \multirow[b]{2}{*}{$\begin{array}{l}\mathbf{P} \\
\text { value }\end{array}$} \\
\hline & $\begin{array}{l}\text { Preeclampsia } \\
(\mathrm{N}=20) \\
\text { frequency }(\%)\end{array}$ & $\begin{array}{l}\text { Severe Pre- } \\
\text { eclampsia } \\
(\mathrm{N}=28) \\
\text { frequency }(\%)\end{array}$ & $\begin{array}{l}\text { Eclampsia } \\
(\mathrm{N}=10) \\
\text { frequency } \\
(\%)\end{array}$ & $\begin{array}{l}\text { Normotensive } \\
(\mathrm{N}=58) \\
\text { frequency }(\%)\end{array}$ & & \\
\hline 37 Тo 38+6 & $10(50)$ & $15(53.57)$ & $2(20)$ & $34(58.62)$ & \multirow{3}{*}{8.596} & \multirow{3}{*}{0.198} \\
\hline 39 То 40+6 & $6(30)$ & $11(39.29)$ & $7(70)$ & $20(34.48)$ & & \\
\hline 41 To 42 & $4(20)$ & $2(7.14)$ & $1(10)$ & $4(6.9)$ & & \\
\hline
\end{tabular}

\section{DISCUSSION}

Earlier recognition and diagnosis of preeclampsia and determining its severity is a crucial step in the evaluation of pregnant women suspected to have such a condition, because preeclampsia with severe features is associated with adverse outcomes including higher rates of preterm delivery, FGR and adverse neonatal outcomes. ${ }^{9,10}$ In present era, many health centers around the world is to routinely obtain coagulation studies as part of the initial assessment of preeclampsia, but the validity of such testing is controversial. Therefore, it is essential to clarify whether abnormal results of such tests are indeed associated with adverse clinical outcomes. In order to evidence this, in this study we divided pregnant females into two groups, based on the presence of high BP readings as preeclamptic (mild and severe), eclamptic 
with at least one abnormal coagulation measure (PT, aPTT, INR) complicating the fetomaternal prognosis and the other group who are normotensive, according to validated pregnancy nomograms.

Table 4: Comparison of activated partial thromboplastin time across study groups $(\mathrm{N}=116)$.

\begin{tabular}{|c|c|c|c|c|c|c|}
\hline \multirow[b]{2}{*}{$\begin{array}{l}\text { Activated partial } \\
\text { thromboplastin } \\
\text { time (minutes) }\end{array}$} & \multicolumn{4}{|l|}{ Study Groups } & \multirow[b]{2}{*}{$\begin{array}{l}\text { Chi } \\
\text { square }\end{array}$} & \multirow[b]{2}{*}{$\begin{array}{l}P \\
\text { value }\end{array}$} \\
\hline & $\begin{array}{l}\text { Preeclampsia } \\
(\mathrm{N}=20) \\
\text { frequency }(\%)\end{array}$ & $\begin{array}{l}\text { Severe Pre- } \\
\text { eclampsia } \\
(\mathrm{N}=28) \\
\text { frequency }(\%)\end{array}$ & $\begin{array}{l}\text { Eclampsia } \\
(\mathrm{N}=10) \\
\text { frequency (\%) }\end{array}$ & $\begin{array}{l}\text { Normotensive } \\
(\mathrm{N}=58) \\
\text { frequency }(\%)\end{array}$ & & \\
\hline 25-30 & $11(55)$ & $13(46.43)$ & $4(40)$ & $35(60.34)$ & \multirow{3}{*}{6.501} & \multirow{3}{*}{0.370} \\
\hline $31-35$ & $8(40)$ & $12(42.86)$ & $3(30)$ & $18(31.03)$ & & \\
\hline$>35$ & $1(5)$ & $3(10.71)$ & $3(30)$ & $5(8.62)$ & & \\
\hline
\end{tabular}

Table 5: Comparison of INR across study groups $(\mathrm{N}=116)$.

\begin{tabular}{|l|llll|}
\hline INR & $\begin{array}{l}\text { Study groups } \\
\text { Preeclampsia }(\mathbf{N}=20) \\
\text { frequency }(\%)\end{array}$ & $\begin{array}{l}\text { Severe Pre-eclampsia }(\mathbf{N}=28) \\
\text { frequency }(\%)\end{array}$ & $\begin{array}{l}\text { Eclampsia }(\mathbf{N}=10) \\
\text { frequency }(\%)\end{array}$ & $\begin{array}{l}\text { Normotensive (N=58) } \\
\text { frequency }(\%)\end{array}$ \\
\hline $\mathbf{1 . 1 5}$ & $15(75)$ & $16(57.14)$ & $7(70)$ & $55(94.83)$ \\
\hline $\mathbf{1 . 6 - 2}$ & $5(25)$ & $10(35.71)$ & $3(30)$ & $3(5.17)$ \\
\hline $\mathbf{2 . 1 - 3}$ & $0(0)$ & $2(7.14)$ & $0(0)$ & $0(0)$ \\
\hline
\end{tabular}

Table 6: Comparison of platelet across study groups $(\mathrm{N}=116)$.

\begin{tabular}{|c|c|c|c|c|c|c|}
\hline \multirow[b]{2}{*}{$\begin{array}{l}\text { Platelet } \\
\text { (lakhs) }\end{array}$} & \multicolumn{4}{|l|}{ Study Groups } & \multirow[b]{2}{*}{ Chi square } & \multirow[b]{2}{*}{ P value } \\
\hline & $\begin{array}{l}\text { Preeclampsia } \\
(\mathrm{N}=20) \\
\text { frequency }(\%)\end{array}$ & $\begin{array}{l}\text { Severe Pre- } \\
\text { eclampsia } \\
(\mathrm{N}=28) \\
\text { frequency }(\%)\end{array}$ & $\begin{array}{l}\text { Eclampsia } \\
(\mathrm{N}=10) \\
\text { frequency }(\%)\end{array}$ & $\begin{array}{l}\text { Normotensive }(\mathrm{N}=58) \\
\text { frequency }(\%)\end{array}$ & & \\
\hline 0 to 1 & $1(5)$ & $3(10.71)$ & $3(30)$ & $3(5.17)$ & \multirow{3}{*}{11.819} & \multirow{3}{*}{0.066} \\
\hline 1.1 to 2 & $11(55)$ & $8(28.57)$ & $4(40)$ & $19(32.76)$ & & \\
\hline 2.1 to 3 & $8(40)$ & $17(60.71)$ & $3(30)$ & $36(62.07)$ & & \\
\hline
\end{tabular}

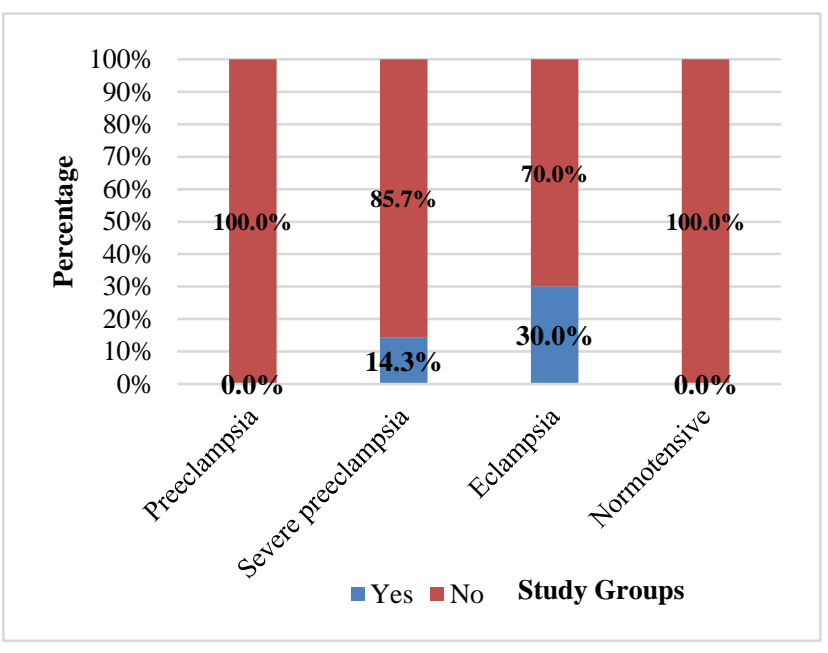

Figure 2: Comparison of bleeding time across study groups $(\mathrm{N}=116)$.

This study showed that the group with hypertensive disorders of the pregnant women with or without abnormal coagulation profile, did not differ much from the normotensive pregnant group with respect to maternal outcomes, including placental abruption features, blood transfusion rates, need for ICU admission and maternal deaths. These results are in line with previous studies, which examined the necessity of coagulation tests in patients with severe preeclampsia and hypertension in pregnancy. Specifically, Leduc ${ }^{12}$ and associates studied coagulation profile, platelet count and fibrinogen, in 100 consecutive women with severe preeclampsia. That study reported that there is no benefit in performing these tests, unless patients present with other clinical morbidity or thrombocytopenia below $100,000 / \mathrm{mm}^{3}$.

One more study confirmed these observations which includes more than 800 women with hypertension in pregnancy. ${ }^{13}$ Furthermore, one more study concluded that there is no need for routine testing of coagulation factors in preeclampsia; however, they did not examine neonatal outcome and placental histopathology, and also did not use the current ACOG criteria for the diagnosis of preeclampsia. ${ }^{14}$ One study found prolonged aPTT in preeclampsia compared to normal pregnancy, but it did not examine the association of this increase with maternal 
or neonatal pregnancy outcomes. ${ }^{15}$ It should be noted that in that study a quantitative statistical method (area under the ROC curve) was used, which is inefficient for differentiating a clinically significant change from mere statistical variance.

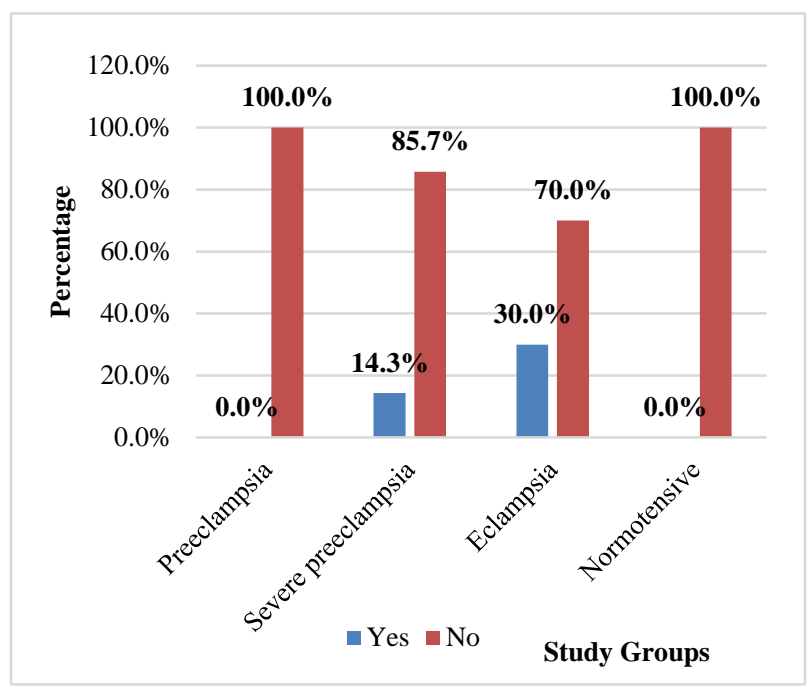

Figure 3: Comparison of clotting time across study groups $(\mathbf{N}=116)$.

\section{Limitations}

This study has several limitations. First, this study is a small, short-term cross sectional analytical study in a singleton tertiary perinatal medical facility. In addition, this study included many relatively mild cases of HDP who were able to complete vaginal delivery and may not be applicable to all cases with HDP. Although the coagulation indices were useful in early diagnosing the cases with HDP, we may had even better investigations to rule out and preventing the complications

\section{CONCLUSION}

In current study with total sample size of 116,20 were preeclamptic and 28 were in severe preeclampsia and 10 were in eclamptic group and 58 were normotensive. This study has shown no significant differences in mean parameters of geographical, age and parity. Preclampsia and eclampsia is a common cause of maternal mortality and morbidity. Many of the patients with decreased platelet count and derranged coagulation profile and other complications associated were more in hypertensive patients than normotensive individuals. Furthermore, studies with large study population is required to evident the necessity of obtaining coagulation profile in pregnant patients for a time period in health care centres.

Funding: No funding sources
Conflict of interest: None declared

Ethical approval: The study was approved by the Institutional Ethics Committee

\section{REFERENCES}

1. Duley L. The global impact of pre-eclampsia and eclampsia. Semin Perinatol. 2009;33:130-137.

2. Steegers EA. von Dadelszen P. Duvekot. Pre eclampsia. Lancet. 2010;37:6631-44.

3. Wallis AB, Safilas AF. Hsia J. Secular Trends in the rate of preeclampsia, eclampsia. and gestational hypertension, United States, 1987-2004. Am J Hypertens. 2008;21:521-6.

4. Mishra DP, Choudhury S, Tudu B. Evaluation of coagulation indices in preeclampsia and eclampsia. $\mathbf{J}$ Evid Based Med Health. 2019;6(17):1316-20.

5. Ohad F. The association between abnormal coagulation testing in preeclampsia, adverse pregnancy outcomes and placental histopathology. Hypertens Preg. 2019;38(3):176-183.

6. Priyanka C, Usha R, Vandana B. Purohit RC. Comparison of coagulation profile in preeclamptic and eclamptic patients with normotensive pregnant patients. J Evol Med Dent Sci. 2014;3(12):3208-15.

7. Mol B. Preeclampsia. Lancet. 2016;387:999-1011.

8. Swetha AG, Puranik N, Kammar KF. A comparative study on coagulation profile and neutrophil lymphocyte ratio in pregnancy induced hypertension. Nat J Physiol Pharma Pharmacol. 2018;8(3):400-5.

9. Buchbinder A, Sibai BM, Caritis S. Adverse perinatal outcomes are significantly higher in severe gestational hypertension than in mild preeclampsia. Am J Obstet Gynecol. 2002;186:66-71.

10. Xiao R, Sorensen TK, Williams WA. Influence of pre-eclampsia on fetal growth. J Matern Neonatal Med. 2003;13:157-62.

11. Abbassi-Ghanavati M, Greer LG, Cunningham FG. Pregnancy and laboratory studies. Obstet Gynecol. 2009;114:1326-31.

12. Leduc L, Wheeler JM, Kirshon B. Coagulation profile in severe preeclampsia. Obstet Gynecol. 1992;79:148.

13. Barron WM, Heckerling P, Hibbard JU. Reducing unnecessary coagulation testing in hypertensive disorders of pregnancy. Obstet Gynecol. 1999;94:36470.

14. American college of obstetricians and gynecologists bulletin. Gestational hypertension and preeclampsia. Obstet Gynecol. 2019;133:1-25.

15. Han L, Liu X, Li H. Blood coagulation parameters and platelet indices: changes in normal and preeclamptic pregnancies and predictive values for preeclampsia. PLoS One. 2014;9:e114488.

Cite this article as: Priya MJ, Ethiraj G, Rangappa SS. A cross sectional study of coagulation profile in term normotensive pregnancy and hypertensive disorders like preeclampsia, eclampsia. Int J Reprod Contracept Obstet Gynecol 2021;10:4258-62. 